\title{
Public versus private land controls in England and the US
}

\author{
Emily Walsh
}

\section{Abstract \\ Purpose}

This paper aims to compare the law with regard to private property rights and restrictions and public controls in England and the US, and the theoretical debates that surround them, in order to understand whether the private land use controls of nuisance and restrictive covenants could have a greater role to play, or whether the public law system of planning is the best way to manage the land.

\section{Design/methodology/approach}

This paper starts by summarising and comparing; firstly, the private laws of nuisance and restrictive covenants and then laws relating public planning, zoning and takings in England and the US. It then reviews theoretical approaches taken in both jurisdictions to land use restrictions.

\section{Findings}

The paper concludes that private land use restrictions can only play a limited role in land management in England. Scarcity and cost of available housing necessitate a mechanism by which the state can intervene in certain circumstances to remove or modify restrictions to enable alteration and development. The structure of freehold ownership in England, and the low take up of Commonhold as an alternative tenure, mean that expansion in the use of private land use restrictions to control the use of land is unfeasible.

\section{Originality/Value}

The value of this paper is that it seeks to provide insight into the contested relationship between private and public law and the relationship between property law and planning.

\section{Keywords}

Restrictive covenants, Land, England, United States of America, Planning, Zoning, Eminent Domain.

\section{Paper type}

Viewpoint.

\section{Introduction}

While carrying out a thematic analysis of responses to the Law Commission's 2008 consultation on easements, covenants and profits à prendre in England and Wales, the writer became aware that some members of the public were extremely anxious to protect private land use restrictions in the form of restrictive covenants. They did not want the law to change in such a way that restrictive covenants became time-limited, or in any way easier to remove from the land register. The general feeling among this group was that restrictive covenants served to temper the greed of developers, 
protect against the corruption of the planning system and ultimately to preserve heritage and open spaces. This led the writer to consider the relationship between private and public law in controlling the use and distribution of land.,

There has been considerable academic debate regarding the extent to which land use should be governed by private property rights and restrictions or public controls. Much of this discussion has centred on the law in the US. The writer therefore decided to carry out a comparison of the law and theory relating to public and private land use controls in England and the US to see whether the US could provide a useful insight into the relationship between public and private law use restrictions in England.

Part I of this article compares the private land use mechanisms of nuisance and restrictive covenants in England and the US. Part II examines the public law controls exerted by planning and zoning, and compulsory purchase and eminent domain. Part III considers the debate on both sides of the Atlantic regarding the extent to which the state should be permitted to intervene in private property. Finally, Part IV draws some conclusions regarding the jurisdictional comparisons made in the preceding parts of the article, and considers whether any normative conclusions can be reached.

\section{Part I - Private land use controls in England and the US}

It is not the purpose of this article to provide a detailed description of the mechanics of private land use controls in England and the US. However, in order to proceed with a discussion of the various theoretical stances, it is necessary to understand a little of how the law works. In both countries the torts of nuisance and trespass control indirect and direct interference with the land of a neighbour, covenants restrict what may be done on one's own land, and easements allow for limited rights over the land of others. It is necessary to briefly consider the private law devices of nuisance and covenants as these provide the alternative to public land use controls.

'The essence of nuisance is a condition or activity which unduly interferes with the use or enjoyment of land' (Jones, Dugdale \& Simpson, 2015, 20-01). Private nuisance often involves noise, smells or pollution emanating from neighbouring land. The interference will generally be indirect, as direct interference in land will tend to constitute trespass, however the distinction may be quite subtle. In English law building a wall on someone else's land would be trespass, whereas failure to maintain a wall, which then falls on a neighbour's land, would be nuisance (Jones, Dugdale \& Simpson, 2015 2001). Actions for private nuisance will usually involve an individual doing something on his land which he is legally entitled to do, and it will therefore be for the court to decide whether the action or extent of the action, is sufficient to unduly affect a neighbour's use and enjoyment of their land. What constitutes a nuisance will, to some extent, depend upon the location of the property; residents of a city are expected to put up with more noise and pollution than residents of the countryside. Whether the defendant's action constitutes a nuisance may also depend upon its social utility. This point is clarified in Restatement (Second) of Torts $\$ 826(b)$, which states that the intentional invasion (of pollution, for example) is unreasonable where the gravity of the harm caused outweighs the utility of the actor's conduct.

The law of nuisance cannot protect an owner from certain activities that may devalue land. Use of neighbouring land that is aesthetically detrimental will not be prevented by nuisance. In the US 
unsightly structures, piles of rubbish, and oddly constructed houses have not been found to be a nuisance (Dodson, 2002, p. 2). Furthermore, nuisance does not prevent the infringement from taking place; it instead relies upon the wronged party instigating legal proceedings against their neighbour. On the one hand, the ability of the wronged party to bring a claim directly against the wrongdoer has certain advantages; it does not rely on the state engaging in expensive monitoring, unlike enforcement action taken by a local authority for a planning infringement. However, it has the considerable disadvantage of requiring a private individual to commence expensive legal action against another private individual. When those individuals are neighbours the consequences may be serious. Quite apart from potential bad feeling between the parties, a dispute may have a negative impact on the value of the property. As Mummery $L$ stated in Cameron $v$ Boggiano ${ }^{1}$ (a boundary dispute), "both sides lose if, for instance, litigation blight has damaged the prospects of selling up and moving elsewhere"

(para. 5).It can be concluded that the law of nuisance operates similarly in both jurisdictions and serves to provide some method of regulating disputes between near neighbours. However, it cannot provide the scope of regulation of land use available through the public planning system.

While nuisance provides a remedy for any party against the infringement of a neighbour, a covenant provides a cause of action only within agreed parameters. A covenant is 'an undertaking contained in a deed by which one party, the "covenantor" promises another party, the "covenantee" that he will or will not engage in some specified activity in relation to a defined area of land' (Gray and Gray, 2009 , p. 237). These undertakings are typically not to build or to carry out a particular kind of use. However, they can be extremely diverse. In a sample of 600 titles analysed by the writer, there were covenants not to interfere with graves, not to keep reptiles, and only to paint in quiet and conventional colours. Covenants differ from the rights in the law of contract which are subject to two important tenets, 'freedom to contract' and 'privity of contract'; the former allowing parties to make such agreements as they wish (subject to only minor legal restrictions); the latter restricting the enforceability of such arrangements to the original parties to the contract. These two tenets are problematic where property rights are concerned; a restriction on development provides little benefit if it ends when the covenator sells his or her land. On the other hand, the longevity of proprietary interests can result in titles to land becoming cluttered. This problem has been identified in England and Scotland for some time. The Royal Commission on Legal Services in England had complained that, 'many thousands of words of restrictive covenants clutter the titles of house property and bedevil modern conveyancing' (1979, para. 3 Annex). Theodore Ruoff, former Chief Land Registrar stated, 'Today these millions of words of restrictive covenants serve no truly useful social public or private purpose' (Law Commission, 1991, p. 121). The Scottish Law Commission stated that past burdens 'clutter up the register and create unnecessary transaction costs' (Scottish Law Commission, 2000 para 5.66).

In both England and the US, covenants are common law devices originating from the English case of Tulk $v$ Moxhay ${ }^{2}$. The facts are well known. A piece of land at Leicester Square was conveyed with a restriction against development. The land was conveyed once more and the defendant wished to breach the covenant. An injunction against the development was granted and was upheld in the

\footnotetext{
${ }^{1}$ [2012] EWCA Civ 157

${ }^{2}$ (1848) 2 Ph 774
} 
Court of Appeal. Lord Cottenham's judgement was brief, and justification of the injunction seems largely to have been based on the fact that the defendant had notice of the restriction. The decision was criticised, writing in 1885 Challis stated, 'the whole principle of Tulk $v$ Moxhay rests upon dubious grounds of equity' (Challis, 1911 p. 185). Another commentator suggested that the interest created by a restrictive covenant was 'received into our system because it serves a useful turn without any question being raised as to the possibility of fitting it into some scientific scheme or legal classification' (Behan, 1924, p. 42).

The rules for transmission of the benefit and the burden of covenants are complicated in both countries and involve common law concepts and equitable doctrine. In England these rules have been criticised by the Law Commission, who carried out an extensive review of the law between 2008 and 2011. The Law Commission found the rules to be complicated and recommended that the system for transmission should be simplified and that covenants should exist in law rather than in equity (except in limited instances where there has been a failure of formality). In the US The Restatement (Third) of Property (Servitudes) (2000) sought to simplify the law of covenants so that the distinction between real covenants and equitable servitudes was abolished, and both are now unified under the term 'servitudes'. The only rules regarding enforcement of a servitude are that; it is in writing satisfying the Statute of Frauds, the beneficiaries are those intended to be benefited by the contracting parties, and that the servitude is not illegal, unconstitutional or against public policy. However, it has been suggested that elements of the Third Restatement have not been embraced by the courts (Russell, 2010; Merill \& Smith, 2013). Unlike the US, in England positive covenants, such as a requirement to maintain a fence, cannot currently be enforced against successors in title to the original covenantor, although reform of this rule has been proposed (Law Commission, 2011 para 5.69).

The perpetual nature of covenants may be problematic particularly where they have become out of step with the needs of society. In English law a statutory mechanism provides for modification or removal of restrictive covenants where certain conditions are met (Law of Property Act 1925, s 84). However, only a handful of cases come before the Upper Tribunal (Lands Chamber) every year. In the US there is no statutory mechanism for removal or modification. However, the conduct of the parties may bring the covenant to an end by merger, release, rescission, unclean hands, acquiescence, abandonment, laches or estoppel. In addition the common law doctrine of 'changed conditions' can lead to modification or termination.

The extent to which the state should be allowed to intervene with regard to obsolete restrictive covenants in the US is controversial. Reichman (1982) argued that the doctrine of changed conditions is necessary as the original parties cannot anticipate and therefore guard against change whereas Epstein (1988) disagreed, arguing that the parties themselves rather than the judiciary are best placed to deal with modification. In England the Law Commission (2008) considered (but ultimately rejected) a 'sunset rule' which would provide a rebuttable presumption that covenants over a certain age should be viewed as obsolete.

The divergence between the law in England and the law in the US with regard to covenants has been significant. However, the principles in remain very similar. Part III of this paper will consider the debate in the US as to whether private land use controls could replace public law intervention. A 
similar debate has not occurred in England. Perhaps one of the reasons why there has been no call for relaxation of public planning regulation in favour of the private law mechanism of covenants is because of the difference in the types of residential landholding in the two countries.

One of the key practical differences between home ownership in the US and England is the popularity of common interest communities. Common interest communities include both homeowner associations and condominium communities, and broadly speaking, they comprise of individually owned unit and shared facilities and common areas which are governed by an association made up of the individual unit owners. Common interest communities have been actively encouraged in the US as a method of reducing costs to the local government. Essentially homeowners pay assessments to the homeowners association which provides street maintenance, parks and other facilities (French, 2005 p. 361).

In England, the Commonhold and Leasehold Reform Act 2002 makes provision for the creation of commonhold, a form on tenure where individual units are owned as freeholds with common areas managed by commonhold associations comprised of the owner of the freehold units. Take up has been extremely low $\mathrm{Xu}(2010$, p. 240) stated that fewer than 20 had been registered since the inception of the Commonhold and Leasehold Reform Act 2002. Whilst commonhold has been extremely unpopular with developers, some commentators believe it provides the answer to the abuses suffered by tenants under the leasehold system (Fetherstonhaugh (2007) and (2014), Driscoll (2008) and (2015) and Dowden (2009)). So whilst approximately $20 \%$ of the US population lived in a common interest community in 2015 (Community Associations Institute, 2015), only 161 commonhold units exist in England and Wales (Driscoll, 2016).

It is clear therefore that while the two main private law mechanisms for controlling land use are similar in England and the US, the structure of land ownership is rather different. This difference reduces the usefulness of covenants as a method of land use regulation in England as compared to the US.

\section{Part II - Public land use controls}

Both England and the US have systems of public land use control that post-date the laws of nuisance and covenants. While there is a body of opinion in the US that favours private over public land use control (see for example, Epstein (1988), (1997) and (2005); Ellickson (1973) and (1982); and Kmiec (1981)), it is worth noting that these public measures were enacted to address a perceived deficit in the private land controls. In summary, this deficit was that nuisance law could not prevent nuisances from arising, but merely provided a remedy when they occurred. Furthermore, they required private landowners to engage in expensive litigation. Restrictive covenants could only be imposed on subdivision of land held by a single private owner, they could not deal with issues affecting larger areas in multiple ownership. This part of the article provides a historical perspective for public land use controls in England and the US and compares the operation and failings of the two systems.

Both in England and the US, increases in the population, and the concentration of population in industrial towns led to poor housing and sanitation. In England, this initially resulted in public health 
legislation, such as the Public Health Act 1875. In the US, New York's Tenement House Act 1901, for example, aimed at eliminating insufficient light and ventilation, undue height, fire hazards, overcrowding, and lack of toilet and bathing facilities. An array of ordinances were enacted to attempt to fill some of the voids left by private land use law; fire zone ordinances, height ordinances and set back ordinances. However these could not prevent the 'hodge-podge' development that was the order of the day (Metzenbaum, 1957, p. 38). In England, early housing and planning policy was driven by fear of disease, and legislation was enacted with a view to clearing slums (Swenarton, 1981, p. 27) rather than provide a comprehensive plan of land use. The Housing, Town Planning Etc Act 1909 was the first piece of planning legislation, and further Acts were to follow every few years. However, it was not until the Town and Country Planning Act 1947 that planning authorities were given powers to refuse or impose conditions on detailed aspects of all development proposals and effective enforcement powers (Ward, 2011, p.101). In the US, The City of New York, which was particularly heavily burdened by overcrowding and haphazard development, appealed for a study on what could be done. After six years, a compendium of information was produced and the committee reported that the only solution was regulation of the use of property. In 1916 New York City enacted the first comprehensive zoning program. It worked by classifying uses into several types and assigning them zones. It also established restrictions on the height and bulk of buildings. With the appearance of a Standard State Enabling Act in 1922 zoning spread and by 1925, 368 municipalities had zoning ordinances (Dukeminier and Krier, 2002, p. 959).

The onset of public regulation of land use was not met with universal approval in the US. New York's Tenement House Act 1901 caused concern amongst landlords who had to foot the bill for the required improvements. Indeed the Act was challenged in court, but was held not to be unconstitutional (Tenement House Department of New York $v$ Moeschen ${ }^{3}$ ). The basis of the challenge related to the eminent domain (or takings) clause of the US Constitution, which states, "nor shall private property be taken for public use without just compensation". There is an important distinction to be made here between regulating and taking. Where land is required by the government for a public use it is able to use it powers of eminent domain to force transfers of property from owners to itself or to other entities such as utility companies, or even private parties (Hawaii Housing Authority $v$ Midkiff ${ }^{4}$ ). The early American practice of eminent domain was heavily influenced by English law (Dukeminier and Krier, 2002, p. 1094). Over time payment of compensation for takings of title became the norm and this is now enshrined in the United States Constitution. Where the government wishes to use its powers of eminent domain to take private property, a legal process known as condemnation occurs. This involves filing a petition in court, notification of interested parties and a trial. Where the condemnation action is successful compensation is determined and awarded. Use of government powers of eminent domain to take the title of land from one private owner and vest this in another private entity is at times controversial and this will be considered later in this paper.

Regulation of land use may result in parties affected claiming that a taking has occurred. This argument can be usefully illustrated in the case of Village of Euclid v Ambler Realty $\mathrm{CO}^{5}$. In this case the Ambler Realty Company began assembling a 68-acre plot of land in the village of Euclid for the

\footnotetext{
${ }^{3} 203$ U.S. $583(1906)$

${ }^{4} 467$ U.S. 229 (1984)

${ }^{5} 272$ U.S. 365.
} 
principle purpose of industrial development. Meanwhile, a zoning commission was appointed and the village adopted its first comprehensive zoning ordinance. This was modelled closely on the New York Ordinance. The ordinance included area districts which effectively dictated what could be built and where. This meant that Ambler Realty could not use the whole of the site that they had assembled for the proposed industrial development and the resultant reduction in value was from $\$ 10,000$ to $\$ 2,500$ per acre. Ambler's legal argument was that the ordinance deprived it of its property without due process of law contrary to the $14^{\text {th }}$ Amendment of the U.S. Constitution. The case ultimately went to the U.S. Supreme Court where it was held that the ordinance as 'a valid exercise of authority' (Village of Euclid $v$ Ambler Realty Co. ${ }^{6}$ ).

Where a private individual argues that an action of the state is a taking requiring compensation, the state may argue that the action is permitted under police powers, and this is what the village successfully argued in the Euclid case. In the US police powers are not defined or even referred to in the Constitution. Broadly speaking, a police power is 'an inherent attribute of sovereignty at all levels of government' (Epstein, 1985, p.108). In Lochner $v$ New York ${ }^{7}$ the following definition was provided, 'those powers, broadly and without, at present, any attempt at a more specific limitation, relate to the safety, health, morals, and general welfare of the public'. These powers enable municipalities to engage in urban planning by producing housing regulation or by enacting zoning ordinances without payment of compensation At the time when the Euclid case was decided there was much at stake as a ruling against the Euclid's ordinance could have raised questions with regard to the New York ordinance on which it had been based. It remains a significant authority for the fact that zoning is a form of regulation and not a taking.

A system of compensation for regulatory losses was attempted in England in the Town and Country Planning Act 1932. The Act provided that owners could recover losses causes by new planning restrictions, but equally the municipality could recover $75 \%$ of any increase in value resulting in changes. Localities struggled to recoup betterment leaving them short of funds to pay compensation. Consequently this policy was a failure (Grant, 1982, p. 21). The situation now in England is that a landowner or prospective purchaser of land may not make assumptions regarding the future use to which land may be put. There is no zoning ordinance to consult. As a result often land is purchased conditionally on obtaining permission for the desired development. Likewise, publically imposed restrictions on land use for environmental or historic preservation may lead to a significant reduction in value for which a landowner will not be compensated. For example in Amalgamated Investment \& Property Co. Ltd. $v$ John Walker \& Sons $L t d^{8}$ the plaintiffs agreed to purchase a freehold warehouse for $£ 1,700,000$. The warehouse was advertised as suitable for development and when asked whether the property had a designation as a building of 'special architectural or historic interest' the vendors replied in the negative. The day after contracts for the sale were signed the Department for the Environment wrote to the vendors informing them that the property had been selected for inclusion in the statutory list of buildings of 'special architectural or historic interest'. The value of the property without redevelopment potential was $£ 1,500,000$ less than the contract price. The lack of compensation for regulatory takings in England was clearly

\footnotetext{
${ }^{6} 272$ U.S. 365,397

${ }^{7} 198$ U.S. $45(1905)$ at 53

${ }^{8}$ [1977] 1 W.L.R. 164
} 
stated by Lord Radcliffe in Belfast Corp $v O D$ Cars $^{9}$. In this case Lord Radcliffe described the extent of legislative interference on a landowner:

... which impaired his right of development, prohibited or restricted his rights of user and, in some cases, imposed monetary charges upon him or compelled him to expend money on altering his property. Generally speaking, though not without exception, these obligations and restrictions were treated as not requiring compensation, though, of course, in a sense they expropriated certain rights of property.

Although there is no compensation for losses occasioned by planning in England there is a system of compensation for compulsory purchase.

In addition to the right to compensation for compulsory acquisition land owners in England have recourse to the European Convention on Human Rights where actions of the state negatively impact on private property rights. There are three principle provisions of the Convention that may apply. Article 1 of the First Protocol protects peaceful enjoyment of possessions, Article 6 provides a fair trial, and Article 8 protects a right in respect to a home. The planning system generally, and compulsory purchase in particular, may be seen as being at odds with peaceful enjoyment of possessions which is protected by Article 1 of the First Protocol. However, Article 1 of the First Protocol does not provide an absolute protection against state interference, there is an important proviso, 'except in the public interest'. Therefore, as long as the system is deemed proportionate it will not be considered to be inconsistent with Human Rights. When the Human Rights Act 1998 came into force incorporating the Convention in UK law, there were concerns that Article 6 would result in a challenge to the UK planning system. The concern was that a policy maker could not also be a decision taker (Pike and Jones, 2002). The courts, however, have found that planning laws and procedures are compliant ( $R v$ Secretary of State for the Environment, Transport and the Regions, ex $p$ Alconbury Developments Limited, $R v$ Secretary of State for the Environment, Transport and the regions ex $p$ Holdings and Barnes plc, $R v$ Secretary of State for the Environment, Transport and the Regions, ex $p$ Legal \& General Society $L t d^{10}$ ). Like Article 1 of the First Protocol, Article 8 is a qualified right and the qualification is broad, 'There shall be no interference by a public authority with the exercise of this right except such as is in accordance with the law and is necessary in a democratic society in the interests of national security, public safety or the economic wellbeing of the country, for the prevention of disorder or crime, for the protection of health or morals, or for the protection of the rights and freedoms of others'. Where a compulsory purchase order is challenged on the grounds of Article 8 it will usually be justified on the grounds that the interests of society outweigh the interest of the individual and that the order is therefore proportional.

The extent to which developments involving compulsory purchase are in the public interest is often controversial. An example of such controversy can be seen in the Olympic Games 2012 hosted in London. In order to make way for the Olympic Park 425 homes were compulsorily purchased and two travellers' sites were relocated (BBC, 2010). Some of the residents displaced by London 2012 complained that compulsory purchase of their homes in the Clay Lane Housing Cooperative resulted

\footnotetext{
${ }^{9}$ [1960] AC 490 at 523-524

${ }^{10}$ [2001] UKHL 23
} 
in the destruction of their community. They appealed against the outcome of the compulsory purchase order on the basis that it was in contravention of their human rights. Ultimately, however, their appeals failed (Bernstock, 2014, pp. 31-32).

The extent to which the state should intervene in private land ownership has proved even more controversial in the US than in England. This is partly the result of some famous decisions regarding eminent domain, most notably case of Kelo $v$ City of New London. ${ }^{11}$ In the Kelo case New London, Connecticut, was designated a 'distressed municipality' with unemployment at twice the state's average and population in decline.The city therefore engaged the New London Development Corporation (NLDC), a private non-profit entity, to assist in planning economic development. The state authorised a bond issue totalling over $\$ 15$ million and Pfizer announced plans to build a $\$ 300$ million research facility in the city. These plans necessitated acquisition of private property and ultimately nine owners refused to sell. These owners argued that compulsory acquisition of their property violated the Fifth Amendment because the taking was not for public use. The question for the Supreme Court was whether the city's proposed acquision of the properties using the power of eminent domain was a 'public use' within the meaning of the Takings Clause of the Fifth Amendment. The court held that 'public use' no longer meant 'public purpose' and that this narrow test had been rejected. They court reviewed the cases (Bernman v Parker ${ }^{12}$, Hawaii Housing Authority v. Midkiff ${ }^{13}$ and Ruchkleshaus $v$ Monsanto $\mathrm{Co}^{14}{ }^{14}$ ) and concluded that these authorities had defined public purpose broadly, stating that this reflected a longstanding policy of deference to prior legislative judgements. They found that the NLDC's plan served a public purpose and therefore that the public use requirement was satisfied. The decision was a 5-4 majority with dissenting judge Justice O'Connor arguing that no property is safe from transfer to another private owner 'under the banner of economic development' (at 2671).To say that the decision was unpopular with the public is an understatement:

Four different polls conducted in 2005 found that over 80 percent of the public disapproved of the Kelo decision, indicating that the decision was less popular than those in late twentieth-century cases about desegregation (including Brown v Board of Education), school prayer, abortion rights, and flag burning (Becher, 2014, p. 14).

The extent to which private land can be compulsorily acquired for another private purpose has also been considered in England. However, the most controversial case was far less emotive than Kelo, partly because the compulsory purchase was overturned, and partly because the parties were large supermarket chains rather than private individuals and therefore the decision did not generate press or public interest. Waring (2013) argues this indifference private-to-private takings does not accurately reflect their significance. The case was $R$ (Sainsbury's Supermarkets $L t d$ ) $v$ Wolverhampton City Council ${ }^{15}$ and it examined the legality of the granting of a Compulsory Purchase Order (CPO) of land owned by Sainsbury in favour of Tesco. Both supermarkets owned land at Raglan Street, Wolverhampton and both advanced competing proposals for redevelopment. Both

\footnotetext{
11125 S Ct 2655 (2005).

12348 U.S. 26

${ }^{13} 467$ U.S. 229

${ }^{14} 467$ U.S. 986

${ }^{15}$ [2010] UKSC 20
} 
proposals required compulsory purchase. Although Tesco only owned $14 \%$ of the land as compared to the $86 \%$ owned by Sainsbury's they proposed that if they were the approved developer they would 'cross-subsidise' the redevelopment of another site. This proposition of redevelopment of two sites swayed the Council to approve in principle the making of a CPO in Tesco's favour. The Supreme Court, by a majority of four to three, found in favour of Sainsbury's holding that whilst 'offsite' benefits could be taken into account this was only the case where these benefits were connected to the proposed development. Lord Walker was mindful of the controversial nature of private takings stating that 'Economic regeneration brought about by urban redevelopment is no doubt a public good, but "private to private" acquisitions by compulsory purchase may also produce large profits for powerful business interests, and courts rightly regard them as particularly sensitive'(at para. 80). Whilst different conclusions were reached in the Kelo and Sainsbury's cases what they demonstrate is the fact that it in both England and the US it is possible for the state to appropriate private land for private purposes subject to certain parameters.

\section{Part III - Some modern theories of private and public property}

Those who expressed their objection to changing the law of restrictive covenants in response to the Law Commission consultation in England were clear that they did not wish the state to intervene in private property rights. The extent to which the state can and should intervene in private property has been the subject of considerable academic debate. As has been previously stated, much of this discussion has been by academics in the US. A review of all the literature and theoretical positions is beyond the scope of this article but some of the main arguments are considered below.

A strict libertarian view of property allows for only the most minimal intervention of the state. In his famous 1974 work Anarchy, State and Utopia, Nozick argues that that the 'night-watchman state' should only intervene to punish violations. Epstein finds that Nozick's thesis ignores significant challenges of common property such as ownership of water or common carriers such as railways and electricity (2005, p. 288). He argues that it is one thing to say that these rules of autonomy, acquisition, transfer, and protection... are indispensible constituents of any legal order, and quiet another thing to say that they alone offer the needed ingredients to constitute a full-fledged state, let alone one that uniquely satisfies the constraints of strong moral theory' (p. 289-290).

Epstein elucidates the distinction made by Calabresi and Melamed (1972) between property and liability rules. Property rules give an individual the right to keep an entitlement unless and until he chooses to part with the right voluntarily, liability rules, on the other hand, permit property to be taken by some other individual upon payment of its fair value (1996-1997, p. 2091). He argues that standard practice of virtually all legal systems assumes the dominance of property rules. However, Epstein is not as strict as Nozick in his libertarian approach to property and does allow for one main situation in which property may be taken and liability rules applied, eminent domain. Epstein believes that eminent domain in necessary to prevent disproportionate hold out costs where property is needed for public purposes. However, he does not support state intervention in the reordering of property rights between private individuals. In his 1982 consideration of freedom to contract and the law of servitudes he dismisses the arguments made by Reichman (1982) and French (1982) that courts should intervene to modify or remove servitudes because of changed conditions (1982, p. 1358). He suggests that parties, being aware that circumstances may change and with 
concern for the resale value of their property or the ability to gift it or to bequest it to their heirs, and with the benefit of legal advice, are more than capable of negotiating suitable provisions for change. He further argues that, in drafting covenants for homeowner associations, developers will be aware that unless provision is made for majority amendment of a covenant, there is a serious risk of hold-out. This risk can be negated by making provision for a mechanism for amendment; perhaps by majority decision (1988, p 919). However, he does not agree that it is for the courts or the legislature to become involved to resolve hold-outs as these are part of the very nature of fee simple ownership of land. In a later article he argues that homeowner associations are like mini constitutions and that parties can sign up to them and alter them via the contractual principle of freedom to contract (1988). He dismisses the concerns of Alexander (1987) that individuals are not always rational and may not understand the covenants pertaining to the land they have bought stating, 'if people cannot contract intelligently, then how can they vote?' (1988, p. 911).

Epstein's positive view of the ability of property to be governed privately by homeowner associations is expanded upon by Ellickson (1982), who argues that there are considerable similarities in the function of cities and homeowner associations. Both may provide services and also restrict the way in which land is used. However, Ellickson argues the main difference is that membership of the city is involuntary whereas membership of a homeowners association is voluntary. He suggests that the voluntary nature of homeowner associations give them a greater degree of legitimacy and that they should therefore be permitted greater powers. As with other libertarians Ellickson believes that public land use controls such as zoning are less efficient and less equitable than private alternatives such as covenants (1973).

Strongly associated to the non-interventionist approach of libertarian property theory, notions of freedom of choice and wealth maximization are also at the heart of law and economics. The significance of law and economics in Anglo-American property theory is clear; indeed it 'dominates contemporary legal academic discussions of the ownership and use of land' (Peñalver, 2009 p. 882). The classic position as stated by Demsetz is that an individual will endeavour to maximise the value of his land (1967). This desire for wealth maximization makes the rational landowner, rather than a collective or public organisation best placed to take responsibility for how that land is used. Planners and regulators do not have the market incentives required to carry out the necessary research to maximise the land's return.

If Epstein opined that the state should intervene only in the most exceptional of circumstances there are scholars who argue that property law has historically paid insufficient attention to social obligation or virtue ethics. Notably among these scholars are Alexander (2008) whose article 'socialobligation norm in American Property law' sets out to expound a theory of property to challenge law and economics. He argues that law and economics reduces the human flourishing to a 'scalar metric' when it is fact much more complex than that (p. 751). Peñalver (2008) agrees with Alexander that 'the complexity of land - its physical complexity, but more importantly the complex ways in which human beings interact with it - undermines the positive claim that landowners will predictably seek to maximise their land's market returns' (p. 827). The fact that land is valued at more than a 'market value' is a feature of many property theories along the political spectrum (Radin, 1982 p. 957). 
Peñalver and Alexander suggest that the interests of future generations are inadequately taken into account in the cost-benefit analysis of current owners. Whilst law and economics scholars such as Demsetz argue that current owners will wish to maximise the future value of their land, Peñalver (2008, p. 856) suggests that they will most likely weigh short-term consequences more heavily:

Lands memory means that the changes we make to the land, once undertaken, will often be very difficult - and at times - impossible to undo. Lost woodlands, derelict brownfields, concentrated poverty, filled wetlands, disappearing topsoil, parched aquifers, and extinct species (or species on the brink of extinction) are the persistent reminders of yesterday's owners' shortsighted land-use decisions.

He argues that other theories of property neglect questions regarding the division individuals and the community in land use decision-making.

Smith perhaps finds a middle way between the non-interventionist view of private property expounded by Epstein and Ellickson, and the more interventionist social-obligation view found in the scholarship of Alexander and -Peñalver. Smith (2009) argues that a range of theories have 'a core consisting of exclusion rights with no-questions-asked liability and a periphery consisting of increasing numbers of governance rules subject to ongoing revision' (p. 967). Smith argues that human flourishing is best promoted through exclusion as it enables individuals to utilise their land to best suit their needs and this enables them to flourish. However, he accepts that the right to exclude 'does not always have the last word' (p. 964). In some situations, Smith explains, where an issue is important enough and a bargain cannot be happen, then an owner's rights must be overridden in preference to larger social interest. The examples he gives are aeroplane overflights, necessity, and antidiscrimination.

The debates outlined above are both interesting and instructive, but it is important to note that the starting point for this discussion was concern expressed by the public about infringement of property rights. This concern arises out of the law as it is, and the law as it might become. Radin, a self-proclaimed pragmatist, states, 'it has always seemed important to me to focus on the non-ideal nature of property practices and institutions, on the situated, and second-best, working out of liberal ideological commitments in practice' $(1993$, p. 1). One might argue, therefore, that the best we can achieve with this consideration of private and public property law is to consider where to place the line. Having considered US scholarship on the subject; it is necessary to consider how the debate has been framed in England. Perhaps the most notable English scholarship comes from Kevin and Susan Gray. Gray and Gray (1998) acknowledge that in the context of contemporary concerns for environmental protection the role of the regulatory state will continue to increase its influence on private property rights (p. 23). They note with regard to restrictive covenants that the regime of private ordering embodied in individually bargained restrictive covenants has now been superseded, in many respects, by the socialised obligations imposed by contemporary planning and environmental legislation' (p. 22). However, they also make that point that restrictive covenants protect against 'disadvantageous development' where the planning system fails to do so (1999, p. 235).

\section{Part IV Conclusions}


The extent to which the state may be permitted to intervene in private property rights is a matter of history, philosophy and politics. What is clear in both the US and in England is that some state intervention will always be necessary. State intervention is considerably greater than the 'night watchman' of Nozick's theory. Provision for roads and other services will require takings of private land for public purposes but the meaning of 'public purposes' and the extent to which land may be taken for private purposes will likely remain contested.

This paper has compared the law in England and the US with regard to private and public land use regulation. It has found broad similarities between the two jurisdictions in both the private law devices of nuisance and covenants, and the public regulatory regimes of planning and zoning, compulsory purchase and eminent domain.

The extent to which public regulations restricting land use are permitted to infringe on private use and enjoyment of land has, it would seem, been more controversial in the academic community in the US than in England. This debate has included detailed argument favouring replacement of public regulation with private governance. This line of argument has not been replicated in England and, to some extent, could not be replicated because the systems of land holding are different. While Ellickson argues that homeowners associations could, and should, be grated greater powers in the US, this argument cannot be replicated in England where homeowners associations do not exist. Commonhold could have served a similar function to the US homeowners associations but, it has proved extremely unpopular as a system of landholding.

Where public concerns regarding state interference with private property rights in both jurisdictions meet once more is with regard to takings of title. Even the liberation theorists of the US accept that eminent domain is necessary to negate excessive hold-out costs but the line between public interest and private benefit, where land is taken from one private owner and vested in another private owner, is likely to remain contested. 


\section{References}

Alexander, G. S. (1987), "Freedom, coercion, and the law of servitudes". Cornell Law Review. Vol. 73, pp. 883-905.

BBC

Becher, D. (2014), Private property and public power eminent domain in Philadelphia. Oxford University Press, Oxford.

Behan, J. C. V. (1924), The use of land affected by covenants and obligations not in the form of covenants. Sweet \& Maxwell, London.

Bernstock, P. (2014), Olympic housing: a critical review of London's 2012's legacy. Ashgate, Farnham.

Calabresi, G. \& Melamed, D. (1972), "Property rules, liability rules, and inalienability: one view of the cathedral”. Harvard Law Review, Vol. 58, pp. 1089-1128.

Challis, H. W. (1911), Law of real property: chiefly in relation to conveyancing (3rd ed.). Butterworths, London

Community Associations Institute (2015). "National and state statistical review for 2015". Available at: https://www.caionline.org/AboutCommunityAssociations/Pages/Statisticallnformation.aspx (accessed 20 September 2016).

Demsetz, H. (1967). Toward a theory of property rights. The American Economic Review, Vol. 57, No. 2, pp. 347-359.

Denyer-Green, B. (2014). Compulsory purchase and compensation (10 ${ }^{\text {th }}$ ed.). Routledge, London.

Dodson, R. D. (2002). "Rethinking private nuisance law: recognizing aesthetic nuisances in the new millennium". South Carolina Environmental Law Journal, Vol. 10 pp. 1-22.

Dowden, M. (2009), "Very little appetite for a change of tenure". Estates Gazette, Issue 917, p. 98.

Driscoll, J. (2008), "A modern perspective to an age-old question". Estates Gazette, Issue 827, pp. 108-109.

Driscoll, J. (2008), “Whatever happened to commonhold?” New Law Journal, Vol 158 Issue 7333, p. 1137.

Driscoll, J. (2016). "Whatever happened to commonhold?" Available at: http://www.leaseholdknowledge.com/commonhold (accessed 20 September 2016).

Dukeminier, J. \& Krier, J. E. (2002). Property (5 ${ }^{\text {th }}$ ed.). Aspen, New York.

Ellickson, R. C. (1982). "Cities and homeowners associations". University of Pennsylvania Law Review, Vol. 
130, pp. $1519-1580$.

Ellickson, R.C. (1973). "Alternatives to zoning: covenants, nuisance rules and fines as land use controls". University of Chicago Law Review, Vol. 40 No, 4, pp. 683-781

Epstein, R. (1985). Takings: private property and the power of eminent domain. Harvard University Press: Cambridge MA.

Epstein, R. A. (1988), “Covenants and constitutions”. Cornell Law Review, Vol 73, pp.906-927.

Epstein, R. A. (1997), "A clear view to the cathedral: the dominance of property rules". The Yale Law Journal, Vol 106, pp. 2091-2120.

Epstein, R. A. (2005), “One step beyond Nozick's minimal state: the role of forced exchanges in political theory".

Fetherstonhaugh, G. (2007), "Developers need a nudge in the right direction". Estates Gazette, Issue 743, p. 292.

Fetherstonhaugh, G. (2014), "A tale of two systems". Estates Gazette, Issue 764, p.15.

French, S. R. (1982), "Toward a modern law of servitudes: reweaving the ancient strands". Southern California Law Review. Vol. 55, pp. 1261-1319.

French, S. F. (2005), "Making common interest communities work: the next step", The Urban Lawyer, Vol. 37, pp. 359-369.

Gilbert, J. A. (1991), "Tenements and takings: Tenement House Department of New York v Moeschen as a counterpoint to Lochner v New York". Fordham Urban Law Journal, Vol. 18, pp. 437-505.

Grant, M. G. (1982), Urban Planning Law. Sweet \& Maxwell, London.

Gray, K., \& Gray, S. (1998). "The idea of property in land", Bright, S. \& Dewar, J., Land law themes and perspectives, Oxford University Press, Oxford, (pp. 15-51).

Gray, S., F., \& Gray, K. (1999). "The future of real burdens in Scots law". Edinburgh Law Review, Vol. 3, No. 2, pp. 229-239.

Gray, K., \& Gray, S. (2009), Elements of Land Law (5 ${ }^{\text {th }}$ ed). Oxford University Press, Oxford.

Jones, M., Dugdale, P., \& Simpson, M. (eds.). (2014), Clark \& Lindsell on Torts (21 ${ }^{\text {st }}$ ed.). Sweet \& Maxwell, London.

Kmiec, D. W. (1981), "Deregulating land use: an alternative free enterprise development system", University of Pennsylvania Law Review, Vol. 130, pp. 28-130.

Law Commission. (1991), Transfer of land obsolete restrictive covenants. (Law Com No 201). HMSO, London. 
Law Commission. (2001), Land registration for the twenty-first century. A conveyancing revolution. (Law Com No 271). TSO, London.

Law Commission. (2008), Easements, covenants and profits à prendre a consultation paper. (Consultation paper 186). TSO: London

Law Commission. (2011), Making land work: easements, covenants and profits à prendre. (Law Com No 327). TSO, London.

Merill, T. W. \& Smith, H. E. (2013) "Why restate the bundle? The disintegration of the restatement of property" Brooklyn Law Review, Vol. 79 No.2, pp. 681-708.

Metzenbaum, J. (1957), "The history of zoning - 'a thumbnail sketch'”. Western Reserve Law Review, Vol. 9, pp. 36-42.

Nozick, R. (1974). Anarchy, state and utopia, Basil Blackwell: Oxford.

Peñalver, E. M. (2009). "Land virtues", Cornell Law Review, Vol. 94, pp. 821-888.

Radin, M. (1982). "Property and personhood". Stanford Law Review, Vol. 34, pp 957-1015.

Radin, M. (1993). Reinterpreting property. University of Chicago Press, Chicago.

Reichman, U. (1982). "Toward a unified concept of servitudes". Southern California Law Review, Vol. 55, pp. 1177-1260.

Royal Commission. (1979), The Royal Commission on Legal Services 1979. (Cmnd 7648).

Russell, A. (2010), "The tenth anniversary of the restatement (third) of property, servitdues: a progress report", University of Toldeo Law Review, Vol. 42, pp. 753-775.

Smith, H. E. (2009), "Mind the gap: the indirect relation between ends and means in American Property Law". Cornell Law Review, Vol. 94, pp. 959-989.

Swenarton, M. (1981). Homes fit for heroes. Heinemann: London.

Ward, S. V. (2011), Planning and Urban Change ( $2^{\text {nd }}$ ed.). Sage, London.

Waring, E. (2013), "Private-to-private takings and the stability of property", Kings Law Journal, Vol. 24 pp. 237-259.

$\mathrm{Xu}, \mathrm{L}$. (2010), "Managing and maintaining flatted buildings: some Anglo Scottish comparisons", Edinburgh Law Review, Vol. 14, pp. 236-258. 